\title{
Current Challenges in Financial Regulation
}

\author{
BY \\ StiJn Claessens \\ WORLD BANK
}

\begin{abstract}
Financial intermediation and financial services industries have undergone many changes in the past two decades due to deregulation, technological advances and globalization. The framework for regulating finance has seen many changes as well, with approaches adapting to new issues arising in specific groups of countries or globally. The objectives of this paper are twofold: to review current international thinking on what regulatory framework is needed to develop a financial sector that is stable, yet efficient and provides proper access to households and firms; and to review experiences regarding international financial architecture initiatives, with a special focus on issues arising for developing countries. The paper outlines a number of areas of current debate: the special role of banks, competition policy, consumer protection, harmonization of rules - across products, within markets and globally and the adaptation and legitimacy of international standards to the circumstances facing developing countries. It concludes with some areas where more research would be useful.
\end{abstract}

World Bank Policy Research Working Paper 4103, December 2006

The Policy Research Working Paper Series disseminates the findings of work in progress to encourage the exchange of ideas about development issues. An objective of the series is to get the findings out quickly, even if the presentations are less than fully polished. The papers carry the names of the authors and should be cited accordingly. The findings, interpretations, and conclusions expressed in this paper are entirely those of the authors. They do not necessarily represent the view of the World Bank, its Executive Directors, or the countries they represent. Policy Research Working Papers are available online at http://econ.worldbank.org.

Paper prepared for the conference: Institutional Foundations for Sound Finance, Prague, February, 27-28, 2006 and presented at the $15^{\text {th }}$ Anniversary Symposium of the Korea Institute of Finance, Finance and Economic Development in Korea, Seoul, November 14, 2006. I would like to thank Amar Bhattacharya for very useful comments and discussions and participants for comments. Contact: Stijn Claessens, Senior Adviser, Financial and Private Sector Development Department, World Bank, 1818 H Street, N.W., Washington, D.C. 20433, phone 1-202-473-3484, secretary 1-202-473-3722, fax 1-202-522-3184, email sclaessens@worldbank.org. 


\section{Table of Contents}

$\begin{array}{lr}\text { Introduction } & 1\end{array}$

1. The developments triggering changes and the changes 2

1.1 Deregulation 2

$\begin{array}{ll}1.2 \text { Technology } & 4\end{array}$

$\begin{array}{lr}\text { 2. The challenges for financial regulation } & 7\end{array}$

$\begin{array}{ll}2.1 \text { Overall approach and the (special) nature of banks } & 7\end{array}$

$\begin{array}{ll}2.2 \text { Competition policy } & 14\end{array}$

$\begin{array}{lr}2.3 \text { Consumer protection } & 20\end{array}$

2.4. Evaluating the costs of regulation 23

$\begin{array}{ll}2.5 \text { Achieving greater harmonization } & 24\end{array}$

3. Special challenges facing financial regulation in developing countries 29

3.1 International financial integration 29

3.2 Cross-border activities, volatility and access 30

3.3 Development strategies, and adaptation of international standards 31

3.4 Political economy 33

$\begin{array}{ll}\text { 4. Conclusion } & 39\end{array}$

5. References 42

Annex 1: 12 Key Standards for Sound Financial Systems 45 


\section{Introduction}

Financial services industries-banks, insurance, capital markets, non-bank financial institutions - have undergone many changes in recent decades. The changes have included consolidation within and across markets, greater cross-border financial services provision, the emergence of new financial products and alternative wholesale markets and trading systems, a redefinition of the role of traditional financial services providers, and the use of new distribution channels, including e-finance. These changes have been triggered by regulatory changes_-notably liberalization locally, regionally, and globally, by market forces, and by technological advances.

In turn, these changes have led to new regulatory challenges and issues. In response, governments have adopted new regulations to assure efficient and sound financial intermediation. While somewhat different approaches are being taken, for many countries much of the impetus for the new regulations is coming from efforts related to regional integration - such as within the EU, for EU-acceding countries and within East Asian capital markets. And, perhaps more so than for any other sector, being very international, financial intermediation has in recent years been subject to a stream of globally formulated and applicable standards and codes. These include the Basle Core Principles on Banking Supervision, transparency and monetary management guidelines, IOSCO capital markets standards, corporate governance rules, etc. Global bodies have been assessing countries' compliance with these standards and codes, as in the joint IMFWorld Bank Financial Sector Assessment Program (FSAP).

Countries, international financial agencies, policy makers and academics are continuously reviewing these new and old regulatory approaches to judge how, if necessary, they can best be adapted. New issues that have arisen include the overall approach towards ensuring a stable and efficient financial system taking into account the changing special role of banks; the approach towards competition policy; how to assure consumer protection effectively and efficiently; evaluating the costs of regulations; and the harmonization of rules across products within markets. In the application of these 
international and other regulations, a number of specific issues have come up for developing countries, for which the globally developed approaches can be more difficult to adopt. The purpose of this paper is to review both the general regulatory challenges as well as the specific issues facing developing countries in terms of adapting to these global forces, both within the financial services industries as well as coming from international regulatory norms.

The structure of paper is as follows. I first very briefly review what have been some key changes in financial systems and financial services industries globally. I also review what have been driving these changes, including the greater emphasis on global standards. I next review how these changes have been leading financial sector regulators to re-regulate in some areas to assure well-functioning financial systems. Issues coming up for review to assure markets function properly and safely have included: the financial safety net, competition policy, consumer protection, managing the costs of regulation, and harmonization of rules. I then review the specific issues facing developing countries, classified in: cross-border activities, volatility and impact on access to financial services; broader development strategies, including questions of the best regulatory approaches; and the relationships between financial regulation and the FSAP/ROSCs processes, and political economy factors. Finally, I end up with some areas of unknowns where further research would be useful.

\section{The triggers and the changes within the financial services industries}

1.1 Deregulation. The financial landscape has been changing rapidly in the last two decades. Market forces, due to or supported by regulatory changes and supported by technological advances, have led to large changes in financial systems around the world in the last two decades. ${ }^{1}$ These changes have in large part been triggered by financial deregulation, i.e., liberalization involving the removal of (close) controls over financial

\footnotetext{
${ }^{1}$ See Rajan (2005) and Beck (2006) for recent reviews of changes in global financial markets. See PadoaSchippoa (2004) for a comprehensive review of the motives for the changes in the financial services industries and the regulatory reasons and responses.
} 
sector activities and institutions. The most important deregulation has been the removal of barriers between products, markets and countries, and sometimes even within countries, such as the U.S. with the removal of intra and inter-state branching restrictions. The progressive elimination of barriers between different types of financial services providers, the removal of barriers of entry and the elimination of product restrictions has led to more competition in financial services industries. The lifting of capital account restrictions, the freeing of cross-border banking in its various forms, including through entry, has taken this increased competition globally.

This deregulation has broadened markets, within countries and across borders, and has triggered large changes in market structures. In most developed countries and in many developing countries, there have been waves of merger and acquisitions as banks and other financial services providers took advantage of larger markets, tried to reap economies of scale advantages and/or positioned themselves against a more intense threat of competition domestically and across borders. There has consequently been consolidation in most banking systems, with the number of banks declining by $1 / 3$ in the US and in the EU. Globally, some financial services segments, such as investment banking, have seen rapid consolidation as well. Following financial crises and triggered by privatization in the 1990s, many emerging markets have seen rapid large foreign entry in their banking systems as well as an increase in cross-border provision in both banking and capital markets' services. As such, many emerging markets are now at the forefront of the process of internationalization of financial services.

Inter-industry changes have been large as well. Most important has been the progressive abolishment of legal separations between commercial banking, insurance and investment banking activities, as most notably in the repeal of the Glass-Steagall Act in the U.S. in 2001. The further removal of many restrictions on products, e.g., the removal of fixed commissions and fees in many capital markets, abolishment of limits on interest rate and credit allocation, the lowering of barriers between products and the reduced emphasis on narrow compliance with product requirements has further intensified competition. At the same time, new players such as hedge funds, on-line financial services providers and 
others have entered many markets and have started to compete with existing players. Changes have also led to a blurring of lines between types of financial services and financial services providers. Insurance, pension and assets management service providers, for example, are now not only competing among each other, but also with each other and are being provided by various types of financial institutions, rather than by the vertical silos of the past.

1.2 Technology. Changes are not due to deregulation alone. Much of change has been due to rapid information, communication and technological (ICT) innovation within financial services industries, with deregulation catching up. Finance by nature is very technology intensive and the large cost reductions in ICT over the past two decades have had large impacts on financial services industries. It is not just that technology today provides an increased ability to engage in high-level finance (e.g., credit derivatives), but it also allows cheaper production and better mainstream financial services for households and smaller size firms. In turn, cost advantages have been passed to consumers in the form of lower margins and better quality services. Technology has allowed for financial institutions to deliver services at greater distance, as when banks deliver financial services without a close presence (say, on-line mortgage services). It is making crossborder provision of financial services easier and cheaper, e.g., witness the improvements in ease and costs of international remittances over the last few years. Besides the costs gains for consumers and firms, technology has allowed for the emergence of new financial markets and trading systems — such as the various stock trading systems, and complete new forms of financial products—such as house-price indexed mortgage loans.

Technology has also affected market structures in many ways, directly and indirectly. The direct effects are many, such as the entry of new financial services providers, e.g., those providing aggregation services putting multiple account information and transaction capacity in one place. Technology is further facilitating the blurring of financial services as financial products can more easily be created, adjusted to user preferences, and delivered. And technology has introduced new players in financial services provision, institutions such as supermarkets, department stores, 
telecommunications corporations and internet providers that have not only the distribution networks and channels — and sometimes large amount of resources, but often also have superior knowledge on customer behavior and preferences.

Indirect effects of technology are many, although sometimes complex. The freeing up of competition in banking in the U.S., for example, is argued to be indirectly technology related. Before the removal of inter- and intrastate restrictions, commercial banks were facing competition from non-bank financial institutions as these non-banks had already expanded nationwide. This increased competition and other market forces in turn helped build up political support for the removal of regional restrictions on commercial banks. This innovation and market behavior was in turn facilitated by technological developments. Technological advances allowed banks and other financial institutions to work around restrictions (some observers have gone as far as arguing that de-facto many restrictions had already been overcome before de-regulation). ${ }^{2}$

Technological advances have also affected the ability of supervisors to monitor banks and have allowed them to be more comfortable with greater competition. While the gains of more competition always existed, prudential concerns traditionally favored limited competition, arguably for two main reasons: in an oligopolistic environment, banks could enjoy extra profit, which would make individual banks and the whole banking system more stable; and in a more controlled environment, regulation and supervision was easier. With better supervision helped in part by technological advances, freeing up banks without inducing instability has become easier for regulators.

The combination of the deregulation and technological changes is leading to many institutional changes, besides changes in market structures. The emergence of financial conglomerates in many countries, for example, is in part the result of deregulation and the increased possibility of using technology to combine multiple financial services and delivering these using the same or similar distribution channels. Thanks to technological advances, new forms of financial services providers have emerged, such as e-brokers and

\footnotetext{
${ }^{2}$ See, for example, Jayaratne and Strahan (1998).
} 
aggregators, and the breadth of financial services available for firms, households, and specialized groups such as lower net-wealth investors, has increased.

Deregulation and technology have, however, also led to more complexity and new risks. Many large banks have become risk managers, rather than traditional providers of financing and liquidity services. This has made especially large international banks very difficult to analyze in terms of their risks and performance. Financial conglomerates have increased in importance and, due to the many links among their various activities, are complex to oversee. New products have been introduced for which risk management systems are yet lacking or only being introduced late even as markets are already large, e.g., credit derivatives. Other new risks come up on a regular basis. For example, in settlement and clearing systems due to greater cross-border trade with associated legal uncertainties, new risks have arisen. The increased competition in capital markets unleashed in part by deregulation and technology has led to more private sector ownership of trading systems (e.g., Archipelo, EuroMTS) and other supportive capital market services. This has led to different forms of oversights compared to the past (when there was largely mutual-or government-ownership), with attendant new issues for not only efficient financial intermediation but also systemic risks. There are now new forms of non-bank means of payment and settlement; although largely still only available in closed systems (e.g., Paypal), they can possibly introducing new risks. ${ }^{3}$

All of this has led to new challenges for the design and implementation of financial regulation and supervision. In the end, many of these challenges center on the tradeoff between efficiency and stability, a perennial issue in financial sector oversight. As such, some of the answers center on well-known themes, having to do with issues of protecting the payments system and financial intermediation, too large to fail financial institutions, the risks of introducing moral hazard, the scope and design of deposit insurance and safety net schemes, etc. But even when the general answers are known-which is not always the case - the tools and interventions of regulators and supervisors have to adapt

\footnotetext{
${ }^{3}$ The issue being debated is whether this is a transactional innovation or whether such private means can provide the final settlement that has been the exclusive role of central banks - as suppliers of private money—so far.
} 
to an ever changing world. The traditional approach based on the silos of financial services provision—banking, insurance, capital markets - surely has to give way to a more integrated approach, aimed at identifying and managing risks in both individual financial institutions as well as in financial markets in a pro-active manner. This will require not just adaptations in supervisory capacity and organization-which we not discuss here, but also changes in regulatory approaches, which we will take up next.

\section{The challenges for financial regulation}

The (global) developments in financial services industries have generally led to improved outcomes in terms of more efficient financial services provision, greater diversity of financial services, and greater access to financial services. Economies - consumers and firms alike - have greatly benefited. Yet, these developments are also leading to new challenges facing financial sector regulators and other policy makers. These challenges relate in large part to financial stability as new, possibly systemic risks arise. Stability is, however, not the only concern of policy makers. New issues also have come up in terms of making financial markets function properly, in the sense of delivering the best possible financial services at the lowest cost to an as wide as possible set of consumers.

For both stability and efficiency purposes, there has consequently been a parallel trend to adapt regulations and adopt new regulations in some areas ("re-regulation") to assure well-functioning financial systems and markets. The design and applicability of these new regulations have been subject to many discussions. Issues arising have been various, but include: the overall approach to financial sector regulation and supervision in light of changes in the special nature of banks; competition policy in financial intermediation; consumer protection; the costs of regulation; and further harmonization of rules and practices. I will discuss these issues in turn, focusing in the next section more specifically on the issues facing developing countries. 
2.1 Overall approach and the (special) role of banks. Liberalization has meant that banks and other financial institutions have moved from being under close control with little competition to having to satisfy minimum prudential standards with more general supervisory oversight and enforcement of good internal risk management practices. In most countries and circumstances, these approaches have led to greater stability; in most developed countries banks and other financial institutions have been able to withstand several large shocks over the last decade (e.g., the late 1990s’ global financial crises, the bursting of the internet bubble) relatively unscathed. Yet, in the first earlier phases of liberalization and in both developed and developing countries, liberalization has contributed to vulnerabilities and even led to financial crises. Some of this was as financial markets' participants and supervisors only slowly "learned" the new world, but some was also due to ill-designed financial liberalization efforts. More recently, some (near systemic) financial crises have been triggered by failures of non-bank financial institutions, such as hedge funds and large corporations engaged in financial transactions, showing that risks can easily arise from (or migrate to) subsectors falling outside the traditional financial system.

As such, each crisis has taught policy makers new lessons and triggered adaptations to regulations. Thinking ahead of what new risks may arise and how to prevent large impacts remains nevertheless a challenge for financial sector policy makers. The full set of issues of financial stability and related implications for financial regulation and supervision are beyond this paper. But there are clearly some general trends underlying the recent changes that require adaptation of approaches at the level of individual financial institutions, at the level of the overall system and at the international level. Many of these changes relate especially to the role of banks.

The role of banks has expanded in recent decades while at the same time banks have shed some of their more traditional forms of financial intermediation. Banks, especially in developed countries, have become more risk managers rather than straightforward intermediaries. Financial institutions most often organized around "banks" are now engaged in a broad range of complex financial transactions and operate in various 
markets - banking, insurance, and capital markets - to take on and lay off risks on behalf of their costumers. They underwrite complex financial transactions, provide specialized over the counter hedging and risk management products, and are engaged in highly leveraged financing operations. They help place financial instruments with other, nonbank financial institutions, such as institutional investors, and take on many advisory roles.

As initially argued by Calomiris and Kahn (1991), Diamond and Rajan (2001) and others, it might be that the combination of a fragile financing structure of a bank-short-term deposits and high leverage — while engaging in risky investments and activities gives a bank (or, currently, a financial conglomerate) the credibility to outsiders that it will manage risks and associated agency problems well. As such, the increased role of banks as risk managers may be a market response and the exploitation of natural comparative advantages. Nevertheless, there are concerns about these trends, concerns, which are mostly, but not only stability related (see further Rajan, 2005). The concerns arise mainly from two, related aspects: financial conglomerates are large and complex to oversee; and financial conglomerates may seek size to maximize potential government support.

The size and complexity of financial conglomerates can make the banking part of the business, the part that is of most concern for systemic reasons, more difficult to monitor for private and official parties. There is empirical evidence for this. Not only has financial institutions' stock price variability been increasing, uncertainty about financial institutions' ratings as reflected in splits between Moody's and S\&P about the rating of a bank's bonds, have increased markedly since 1986 (Morgan 2002). Differences of opinion among analysts are also greater for banks than for corporations. Morgan (2002), for example, finds that uncertainty about banks' valuation is markedly higher than for other industries. Judging from equity price to book ratios, the market also seems to be discounting banks more than other corporations. 
In addition to concerns about market monitoring, specific concerns have been raised for a long time now with regards to large, complex financial institutions - LCFIs in short(e.g., going back to the so-called Ferguson G-10 report of 2001). Besides the difficulty markets and supervisors may have to assess conglomerates, LCFIs may be too big to ignore or too complex to fail by supervisors. As such, they may get preferential treatments during periods of financial stress. And while the safety net is surely not the main reason for the emergence of large conglomerates, financial institutions may have an incentive to grow and become more complex to maximize the benefits from a public financial safety net. While LCFIs have been an issue for regulators globally for the last decade, no easy solutions have been found to limit any benefits from a public safety net. Of course, the reasons to treat banks— and financial conglomerates by extension— special may itself be subject to debate (see box 1).

\section{Box 1: The changing special nature of banks}

Why banks are "special" and what it means for regulation (and supervision) has been analyzed many times and is clear in principle (see, for example, Goodhart, 2000, or Padoa-Schippoa, 2004 for a review). But the dramatic recent changes in financial services provision calls for continuous inspection of this aspect.

In some respects, banks are getting less special, reflected in part in a decreased role of traditional banking products (payments, deposits and credit) in overall financial intermediation. The share of banking credit in total financial intermediation, for example, has fallen by half in many developed countries. Corporations can now get liquidity at very short-notice from capital markets and non-bank financial institutions. Households can have access to mutual funds to meet their liquidity needs. As traditional liquidity providers, an important reason to treat banks special, banks may thus have become less important.

The changing, and perhaps less special, role of banks is arguably partly recognized in financial markets. There are signs, for example, of increased applications of principles traditionally used for non-bank financial institutions to financial institutions. This includes bringing financial reporting closer to corporate sector reporting, applying standard corporate governance, market discipline and the like principles to banks, and moving away from compliance supervision towards more risk management based supervision. Increased application of corporate finance tools can also be found in banking research. But how government policy, especially with regard to the public safety net, needs to adjust to these changing roles of banks has been less clear. So far, the traditional model has largely been maintained. 
These developments are also raising new regulatory issues for non-stability reasons. Generally available evidence suggests that improved and market discipline corporate governance for corporations translates also to financial institutions-leading to better performance, more efficient operations, less expropriation of minority shareholders by controlling owners, etc. The greater uncertainty about bank valuation and the fact that banks are more opaque than most other corporations - and may become even more opaque - may mean, however, that there are limits in how far market discipline and corporate governance can encourage efficiency and good performance for financial institutions. Whether there is much scope for beneficially adapting general, non-financial corporate governance regulations to the specific issues of banks or financial conglomerates remains to be seen. One proposal has been to require banks to issue subordinated debt, but few countries have done so to date.

In addition to these concerns at the level of individual financial institutions, the degree and nature of spillovers among financial institutions and through financial markets has become much more complex to predict, measure and manage. In the past, spillovers of a financial institution running into financial distress on other financial institutions might have been easy to predict, as the bank engaged with a limited number of clients in a significant way. Today in many financial markets, spillovers are much harder to predict. Even the relatively straightforward analysis of predicting how turbulences get transmitted through the interbank market has become quite complex as there are so more actors and exposures have become so much more complex. The broader issue of how liquidity shocks get passed on through various financial markets has become even harder to analyze as the transmission mechanisms are so much more complex today. Similar sized shocks may affect financial markets quite differently at various points in time, but why remains unclear. The spillover of the LTCM collapse, for example, surprised many close observers and still remains largely a puzzle today for researchers.

The specific solutions are not yet known, but there are clearly some general implications from the experiences to date. The foremost is that a "cylinder" approach to regulation and supervision may not longer be suited for many countries. The cylinder approach involves 
treating commercial and investment banks, insurance companies and securities markets intermediaries as separate institutions with their own set of regulations and separate forms of oversight. This approach is reflected in the current set of standards and codes, most of which have been adopted post-1990s financial crises and which include the Basel Core Principles for Banking Supervision, the IOSCO principles for capital markets, the IAIS for insurance markets, and other templates. ${ }^{4}$ These standards and codes are organized by the types of financial institutions. But, as isolated entities, these often no longer exist in many financial systems. While systems have worked relatively well so far, it is also true that most financial system remain untested following the crises of the late 1990s. Therefore, it is unclear how well or poorly the approaches deal with (systemic) risks.

The close congruence between commercial and investment banks in most developed countries and the close links between insurance corporations and commercial banks in many financial systems suggest, however, that risks will not be isolated to one type of financial institution. Consequently applying standards and supervision by separate types of financial institution makes little sense these days. Instead of a cylinders-approach, a more general risk management approach will be needed, at the individual institution and at the system level. These more risk-management oriented approaches should focus on balance sheet risks. The new Basel II approach and the solvency guidelines being developed for insurance corporations are already based on the adequate measurement and management of risks and the holding of capital as a buffer against any unexpected risks. Pension funds and pension fund regulators are also adopting more risk-based and balance sheet approaches. While there may be congruence in approaches, the basic principle, however, is still one of management of risks at the separate financial institution level. What is needed because of the increasingly complex ways through which financial risks are being managed by banking, insurance, and securities firms is a cross-sectoral approach.

\footnotetext{
${ }^{4}$ Of these, twelve are the so-called core codes (see Annex 1).
} 
The first step towards integrated risk management approaches and corresponding regulation and supervision would be the identification and standardization of the common themes and elements in the various standards and codes. Commonly mentioned in many of the codes are the importance of independence of the supervisor and local standard setters, adequacy of financial and human resources, and proper regulatory governance; the need for transparency, disclosure and governance of financial markets participants; and the importance of certain key infrastructure elements such as clearing/settlement and payments systems (and have been highlighted, among others, in the 2004 IMF review of regulatory systems aimed at identifying common regulatory themes). The second step would be to try to develop a more common approach in strengthening regulatory regimes. This could involve separate assessments of the elements common across all sectors rather than through the now typical sector-specific assessments. Subsequently, policy and technical assistance should aim at strengthening foremost these common elements. A third, accompanying step would be to acknowledge the greater relative importance of some codes and other institutional infrastructure to financial system functioning. Clearly, accounting and auditing, and governance have come to be recognized to be core ingredients as regulatory agencies are moving towards more sophisticated risk-based regulatory techniques in a more financially integrated world. The whole institutional infrastructure for assets identification and treatment - e.g., the availability of credit information, the registration and perfection of collateral-and the framework for financial restructuring, including reorganization and insolvency, have also moved more to the forefront.

There are also some specific lessons. For one, there may be an argument for having higher transparency requirements for banks and other financial institutions than for nonfinancial corporations. Accurate reporting on a detailed and timely basis of financial performance and material events can improve market discipline. However, while in general improved transparency has been part of the re-regulation agenda, it has encountered some tradeoffs for financial institutions. Too little transparency is surely unwelcome, but too much transparency has been argued to be potentially volatilityinducing. This has come to the forefront with the choice of more mark-to-market IAS 
accounting rules for banks' activities in financial derivatives, which has been argued to introduce mostly a noisy signal. While the final choices are still be made, it seems there is general agreement that at times a balance have to be made with regard to the degree of transparency as applied to financial institutions.

There may also be a need for special corporate governance features for financial institutions. Some tools have already been proposed to deal with the specific issues of financial institutions, largely to assure stable financial institutions. This includes the use of subordinated debt, to be traded and repriced frequently, to induce more active monitoring by markets of banks (few countries, though, have adopted this as a formal requirement). One also could envision other requirements. For example, special requirements can be imposed on the quality and independence of members of a financial institution's risk management committee. Or specific liability requirements for directors of financial institutions can be imposed to compensate for the possible negative externalities of the failure of a financial institution.

In terms of the systemic aspects of risks, conclusions are unclear. Given how difficult it is to anticipate the ways in which risks get transmitted, it is hard to determine how to make systems more robust and how to prioritize interventions. It is probably the case that there will be a greater need to protect the basic elements of a financial system: payments system, clearing and settlement, and the basic provision of liquidity. And indeed, much effort has been invested in strengthening these basic elements of the institutional infrastructure, also at the international level. Scenarios and financial crisis games can help identify general financial vulnerabilities and possible gaps in decision-making processes. There are undoubtedly many specific elements that can be undertaken to make financial markets function more effectively in dealing with risks, but what the returns of each intervention are and what that means for prioritization is less clear. There surely will be tradeoffs. Too well functioning financial markets may facilitate too easy transfers of risks and "some sands in the wheels" can be attractive at times. Too poorly functioning markets at the same time can exacerbate liquidity shocks as needed markets suddenly “disappear”. 
2.2 Competition policy. Competition has been an important driver of recent financial sector improvements. Making financial systems more open and contestable has generally led to greater product differentiation, lower cost of financial intermediation, more access to financial services, and enhanced stability. The evidence for these effects is fairly universal, from the U.S., EU and other developed countries to most developing countries. As globalization, technology and de-regulation further progress, the gains of competition can be expected to become even more wide-spread across and within countries. At the same time, the rapid competitive gains due to the first rounds liberalization over the past few decades will be harder to sustain. Importantly, new regulatory and competition policy issues will arise as financial markets and products become more complex and global (see further Claessens 2006, and Claessens et al. 2003).

The rapid gains in the US, and the EU due to intra-country and -regional deregulation, and the large progress in developing countries' banking systems that opened up and experienced large entry-for example, Central and Eastern Europe and Latin America - will be hard to replicate in the future. Extending the gains to all types of consumers of financial services has not proven easy either. Gains from increased competition can be limited to certain segments and are not necessarily widespread. In most countries, the major gains from increased competition have come first and foremost to the wholesale capital and corporate finance markets. Even in the most developed countries, with good financial institutions and solid institutional infrastructures, the degree of effective competition in consumer and retail services still lags that in other financial services segments (and indeed the EU has made improving competition in these segments a priority in its Financial Sector Action Plan, 2005-2010, see European Commission 2005).

Assuring that all the potential gains from competition are achieved is difficult, and not just a matter of opening up more. The Cruickshank report in the UK (2001) showed that barriers for consumers and SMEs are often subtle and not easy to correct. More disclosure to consumers on the costs of various financial services can help, but experiences show that this remains of limited effectiveness when done by government 
fiat alone. Some strong policy intervention can at times be necessary to force adjustments, create standardization and remove barriers. This has happened over the past decade in many countries when governments required various retail payments systems developed by (groups of) individual banks within a nation to be integrated and available to all consumers. It has happened recently in the EU when the EU required that the charges for financial transfers among Euro-zone countries had to equal that for domestic transfers (subject to some conditions). Mandating in this way a level playing field can be equally necessary in capital markets to assure fair trading for small as well as large investors. In the U.S., for example, traders are required to use the best price. This is embodied in the SEC order protection rule: no matter where a customer order is routed, it should receive the best price that is immediately and automatically available anywhere in the national market system. This principle promotes competition among individual market centers by ensuring that dominant markets cannot ignore smaller markets displaying the best price.

Improving access and financial inclusion can require some specific measures, not just complementary to those increasing competition, but partly to offset possible negative effects of competition. In some circumstances, increased competition can have adverse effects on access to financial services, as in case of relationship-based lending, as has been found for the U.S. and some European markets (Boot and Schmeits, 2005 review). More competition can undermine the incentives of banks to invest in information acquisition and lower their lending to information-intensive borrowers. More generally, the more formal lending arrangements often associated with consolidation, increased foreign bank entry and greater use of technology may have adverse impact on access for some classes of borrowers. Specifically, the risk exists of bifurcated markets: large (international) banks will concentrate on large corporations, serving them using domestic and international platforms with a wide variety of products, and on consumers, providing them with financial services based on advanced scoring techniques and the like. The left out, middle segment under such a scenario would be the SMEs. As competition intensifies, profitability may go down and banks would have little incentives to invest in longer-term relationships based lending and information collection. 
Even in market segments where competition has been intense and benefits in terms in access and costs have been very favorable, such as wholesale and capital markets, new competition policy challenges has arisen, nationally and internationally. This is largely because the forms of financial services provision have changed so much in the last decade. The consolidation of financial services industries, the emergence of large, global players, the large investments in information technology and brand names necessary to operate effectively and to gain scale, and the presence of large sunk costs make it difficult to assure full competition, even abstracting from the special characteristics of financial services. The presence of high fixed costs and large sunk costs in the production of whole-sale financial services, for example, can mean significant first mover and scale advantages, possibly leading to natural monopoly and market power. In consumer finance, large switching costs-for example, when automatic payments are linked to one's specific bank account number-can mean that customers do not easily change provider. Externalities, say in e-finance, for example, in the adoption of payments using mobile phones, can make the adoption of new technologies exhibit critical mass properties.

Financial services provision also involves the use of a great number of networks, such as payments, distribution and information systems. This means barriers to entry can arise due to a lack of access for some financial services providers to essential services. In banking, barriers are closely related to who has access to the payments system, typically limited to banks. ATM and other distribution networks can further be limited to banks. Access to credit and other information is often limited to (a subset of) incumbent banks. In addition, network externalities_especially in capital markets, e.g., the agglomeration effects of liquidity — can complicate the application of competition policy. Ownership and governance structure play a role. In many stock exchanges, derivatives and other formal trading markets, ownership and governance structures are changing from mutual to for profit, with fewer owners. This can make traditional means of ensuring competition work poorly, or at least, different approaches are required. ${ }^{5}$

\footnotetext{
${ }^{5}$ A private provider of an essential service will have different incentives to serve all in need than a mutual owned provider.
} 
In addition to these complications, market and product definitions have become (more) difficult. It is somewhat trite, but nevertheless very important from a competition policy point of view to state that many financial markets today are global in nature, making any application of competition policy to national markets of lesser value than in the past. In addition, the definition of a specific financial service (and its market) has become more difficult. Today, for example, there are fewer differences than in the past between the markets for pension services and that for assets management services, like the US 401-K plans; after all, many people can save in both ways. And with many non-financial institutions providing (near) banking and other financial services, the boundary between banks and non-bank financial institutions has become more blurred. There are also forces towards vertical integration in some aspects, especially in capital markets (e.g., the integration of trading systems with clearing and settlement), while other forces push towards more separation in other aspects (e.g., clarity in functions) or horizontal consolidation (e.g., economies of scale). Each of these forces creates its own set of competition issues. Finally, the "special nature" of finance, with its emphasis on stability, always meant that competition policy was considered more complicated in the financial services industry. Licensing, for example, was in part used as a prudential policy, with less regard for its impact on competition.

There are no easy answers to many of these issues, and the theoretical and empirical literature is just catching up with the changes in financial services industries. Nevertheless, elements that have to be considered include the following:

- The institutional arrangements for competition policy often will need to change. For one, there is much more need to coordinate better, and preferably bring together, competition policy functions now often dispersed among various agencies within countries (e.g., separate for banking and non-bank financial institutions, or with prudential regulators, or among both specialized and general competition policy agencies). The changing nature of financial services provision also means that many other actors and aspects affect the 
competitive environment for financial services provision (e.g., telecommunications as it may affect the market structure for e-finance). And, obviously, there is a much greater need today for international cooperation among various national agencies in the application of competition policy. Related, competition policy needs to be separated more clearly from prudential oversight. Some countries have already taken consumer protection out of the central bank or supervisory authority, but in many countries the responsibility for competition policy still lies with the prudential authority. This creates conflict of interests ${ }^{6}$ and hinders the buildup of skills necessary for proper competition policy analysis.

- The new forms of financial services provision means that approaches to competition issues need to be adjusted. Competition policy approaches need to resemble those used in other network industries, such as telecommunications, energy, and water. This would mean that the various inputs required for the production and distribution of financial services, including network services, need to be available to all interested in using them, be fairly and uniformly priced, and be efficiently provided. For no part of a specific financial service production and distribution chain, should there be any undue barriers or unfair pricing. These steps are considered basic requirements in most other network industries when (private) firms are producing and delivering services using common networks. One can go even further and have "universal service obligation” or uniform price rules for essential inputs in producing financial services as exist in other network industries.

- Corresponding to the changes in financial services industries, the tools for identifying and addressing competition issues need to be adjusted. Clearly, the measures typically used to date for measuring lack of competition (e.g., Herfindahl or concentration indexes of banks or branches within a geographic

\footnotetext{
${ }^{6}$ The EU E-money Directive - specifying that the issuance of electronic money is subject to bank-like licensing and prudential controls - is arguably such an example. The fact that other countries such as the US did not carry this limitation and that the EC itself in its 2005 White Paper finds that this "may have constrained market developments" suggest that it may have been the self-interests of monetary agencies (and incumbent banks) that led to these (anti-competitive) rules.
} 
area) are quite limited given the changes. Yet, the more sophisticated analytical and empirical tools developed for measuring competition in other industries are hard to apply to financial services industries given the unclear production function for financial services, the tendency to produce and sell bundles of financial services, the weaker and more volatile data, the presence of network properties, etc. For example, it has been difficult to measure effectively competition in banking using the tools from the traditional industrial organization literature (such as pass-through coefficients). Tools thus need to be enhanced. Some information on the competitive structure can still be discerned by focusing on price setting for specific products or financial functions, e.g., what are the fees being charged for consumer retail products or for processing individual pension premiums or payments. In addition, more focus can be given to the pricing and availability of inputs necessary to produce financial services, e.g., assure that all types of financial institutions have access on the same basis to the retail payments system.

2.3 Consumer protection. The increased diversity of financial instruments and larger number of financial institutions active in many markets has led to many gains. At the same time, the more diverse and complex products and the changing markets have made it more complicated to assure that consumers gain all the benefits from this diversity. In banking, while product innovations for consumers have been more limited, delivery channels have changed quite a lot and many new players have emerged, making it harder for consumers to choose on a well-informed basis. In financial markets, many new products have become available to consumers, making for complex choosing even for sophisticated investors. Policy responses motivated by concerns over consumer treatments have been multiple and have not alone or primarily been aimed at what is traditionally called consumer protection. Since the dividing lines between consumer protection, competition policy and assuring properly and integrally functioning financial markets that allocate resources efficiently can be somewhat arbitrary, we divide the issues here into: assuring markets work better for all final consumers — what is sometimes called “assuring a proper business conduct”; protecting individual consumers; and 
assuring consumers obtain the greatest benefits from financial services provision through proper information and education.

Assuring a proper business conduct. This policy goal is especially applicable to capital markets. The many changes in stock, banks derivatives and other formal trading markets, including ownership and governance structures, can make self-regulation work poorer, and raise issues of oversight and conflict of interests. More generally, and also in light of the recent lapses in governance and market conduct in even the most developed countries, there has been a perception that on a systematic basis financial markets have not been functioning for the interests of all final consumers, especially not for small investors. ${ }^{7}$ In part these "lapses" have been triggered by rapid changes in industrial structures, with regulation and oversight only slowly catching up.

Among others for this reason, conflicts of interests have been (further) limited through the separation of some aspects of commercial and investment banking functions - such as research, and rules of conduct have been further enhanced. In capital markets, regulators have responded by taking on some oversight functions listing requirements and brokers licensing specifically but also others that were previously undertaken by (or delegated to) stock exchanges and other self-regulatory organizations and associations. Following many scandals, accounting and auditing have had a sea-change in regulatory oversight structures, moving away sharply from self-regulation to government oversight structures. More generally, regulators have stepped up their oversight to assure, among others, fair consumer treatment. Disclosure requirements on conflict of interests and liability of all types of financial services providers have (further) increased, either by legislation or by stricter application of existing laws by the judicial system (e.g., in the U.S. by the NY attorney general and the SEC).

\footnotetext{
${ }^{7}$ In the U.S., for example, the fact that mutual funds managers gained advantages by trading at late prices hurt small investors; it was a systemic pattern, yet not acted upon for a long time. Similar issues where financial services industries on a systemic basis had favored the rules to its own interests had arisen in the lack of decimal trading at the NASDAQ in the early 1990s. More recent in the selling of insurance policies "contingent commissions" or "overriders" were used which are fees paid based on the volume and profitability of insurance business generated by brokers. They provide an incentive for insurance brokers to recommend more costly insurance to their clients, presenting a conflict of interest.
} 
Protecting individual consumers. For a period of time now, financial institutions have had to comply with greater responsibility of truth in advertising and providing more information to consumers. Yet, the policy of "buyer beware" has shown to be of limited effectiveness in protecting consumers. Put differently, providing more information alone has shown not to be the full answer to assuring that products are of fair value and match consumers' knowledge, preferences and abilities. At the same time, a more liberal environment by definition cannot have regulators checking individual products for fair value or other consumer attributes. Rather, it is increasingly recognized that financial services users themselves need to be equipped with the legal and administrative tools to take action against misuse. This greater emphasis on private rather than public enforcement in consumer financial services mimics the findings from capital markets, where private enforcement has found to be more effective for capital market development (La Porta, Lopez-de-Silanes and Shleifer, 2006), and from banking systems, where the three pillar approach of Basel II includes more emphasis on market oversight and disciplinary actions (Barth, Caprio and Levine, 2006). This approach would imply, inter alia, that consumers can more easily sue financial intermediaries, that class-action suits are allowed, that specialized courts or institutions exist to handle small financial services claims, that more material information is provided on a routine basis, that conflict of interests are more clearly revealed, etc. Many countries are moving in this direction, but the speed varies and bottlenecks remain, including judicial systems that yet have to develop the expertise to deal with (complex) financial cases.

Assuring consumers obtain the greatest benefits. Still, even if all measures are implemented —and some countries are further along on this path, these efforts alone do not necessarily make for well-informed decisions. The bewildering choices of financial instruments make it hard to compare the true all-in costs, risks and fits of an instrument with the individual consumer's needs and preferences. The less-well educated may be easiest misguided, and more so than in the past, about the gains of new financial instruments. As Alan Greenspan has noted: “Today’s financial world is highly complex when compared with that of a generation ago. Forty years ago, a simple understanding of how to maintain a checking and savings account at local banks and savings institutions 
may have been sufficient. Now, consumers must be able to differentiate between a wide range of financial products and services, and providers of those products and services.”8 While consumers may have the information, they often do not read or understand the material provided or choose to ignore it, especially when induced by the latest fads or fashion. And mis-information and herding effects are becoming easier in an internet and mass-communication world.

This is not an issue of consumer protection in a narrow sense as the products offered may satisfy all fair, equal opportunity, etc. requirements, but more of getting greater welfare benefits from financial services provision and financial liberalization. As noted, it is especially the less well-educated which stand to suffer the most with the increased complexity. As such, increasing financial literacy is an obvious policy prescription to this issue. But this has proven to be difficult. Although governments have stepped up efforts to increase financial education, it has proven hard to teach individuals on the details of financial services. A study produced by the OECD's Financial Education Project (2005) concludes that given the (increased) complexity of financial services, education about finance, and how it works, must be incorporated into basic education systems, a long-term undertaking. It also found that specific financial education programs can work, but might not always be the most effective approach. ${ }^{9}$

2.4 Evaluating the costs of regulation. As in other areas of economic activity, a perennial issue is assuring the right balance between the private (and public) costs and the public (and private) benefits of regulation and supervision. While there has been much financial deregulation, there has also been much re-regulation to make markets function more effectively, efficiently and sound. With the many new regulations and regulatory changes in recent decades arising from global, regional or national initiatives, new costs have been imposed on financial services industries. These costs have come in the form of direct expenditures on compliance, increased reporting, further internal system

\footnotetext{
${ }^{8}$ As recited in the Keynote Address "Importance of Financial Literacy in the Global Economy” by The Hon. Donald J. Johnston, Secretary-General of the OECD, to the Financial Education Summit, Kuala Lumpur, 12 December 2005.

${ }^{9}$ The OECD has published a set of principles and good practices for financial education and awareness OECD (2005).
} 
development, etc. Furthermore, excessive or over-regulation can lead to inefficiencies in financial services production and provision, as when banks can not choose the least cost options to distribute financial services (for example, when regulation requires separation of some functions). These additional costs and inefficiencies will be passed on to the final consumers through increased costly financial intermediation. Overregulation can also hinder access to financial services. The Anti-Money Laundering (AML) and Counter Financing of Terrorism (CFT) rules, for example, have been argued to make it more difficult for low-income people and those without regular jobs or residence to open up a bank account or to transmit remittances.

It has been argued indeed by some that the costs and forms of regulation have increased beyond what is reasonably justified and that it is time to take stock, limit new regulation and consolidate and streamline existing rules. The recent White paper on the EU Financial Sector Action Plan 2005-2010, for example, stresses the need for better, not more regulation. As in other industries, governments need to avoid over-regulation and assure that they do not impose too high compliance costs on financial services industries. To achieve this goal requires continued impact assessments of new or modified regulations and performing consistently rigorous costs-benefits tradeoffs. Also, governments can create greater consultation and transparency in their rule-making processes so as to allow a better reflection of financial services industries' views. Such assessments and consultations should be part of standard rule making processes not only nationally, but increasingly as well regionally and internationally.

Yet, greater consultation also invites regulatory capture, a problem especially severe in emerging markets (Barth, Caprio and Levine, 2006), where it can happen in quite blatant ways (e.g., the "buying" of a license for a bank). But it is also prevalent in more subtle ways in developed countries: the rules of Basel II, for example, have been argued to be heavily influenced by large international banks (Claessens, Underhill and Zhang, 2003). Obviously, consultation is a complex process, especially internationally, given the many parties involved and the various issues at stake, and no easy models exist to balance various interests. The general point though is that to date, as in many other sectors, the 
process has favored the producers rather than the consumers. To be useful, the consultative process has to be broad enough to include all stakeholders, including consumers and businesses, not just financial institutions. This requires balancing the powers of various interest groups properly and may require proactive measures. For example, consumers are typically poorly organized and may need to be equipped with resources and expertise to be an effective influence. This in turn may call for government actions.

2.5 Achieving greater harmonization. Associated with the need to evaluate the costs and benefits of regulation is a need for greater harmonization of regulatory approaches across sectors and products and the elimination or reduction of barriers impeding the efficient production and provision of financial services. Harmonization is needed both among financial services providers (banks, insurance companies, pension funds, asset management, etc.) and between different, but functionally equivalent types of products - whether called banking, insurance, or capital markets products. Harmonization across sectors and products is needed to avoid regulatory arbitrage, level the playing field, increase competition, and reduce differences in the overall regulatory burden of products. The increased ability to create complex financial products and unbundle risks, straddling in the process various markets and institutions, makes the need for a common regulatory approach all the more necessary. Harmonization's goal should be that, within markets, products are not regulated differently depending on what type of financial institution provides the service. And products that offer the same functionality of service, but may be "labeled" differently, i.e., fall under different regulatory approaches, need to be treated similarly.

Harmonization across sectors and products is a long-standing issue. On one hand, the big barriers across sectors and products have been removed: only in some countries, but increasingly less so, there are still (large) regulatory barriers between commercial banks, investment banks, insurance companies and other financial institutions. The fact that these large barriers have been removed, however, does not make the issue moot. Rather there is a need to go more in depth, which, however, can be conceptually and in practice 
very difficult. Due to path dependence (e.g., some products emerged as insurance products but migrated to becoming savings products), the existence of subtle barriers (e.g., some products may be linked to the payments system for which access is limited), or because of linkages with other economic policies (e.g., taxation may be linked to pension but not to savings), leveling the playing field has often not been easy. Furthermore, many financial products come bundled (e.g., a checking account has both savings, payments and often as well credit—overdraft-functions linked to it), making it hard to compare regulatory burdens of individual products with each other (e.g., the costs of complying with AML/CFT may be assigned to a checking account or may be spread over various products). Much more work is needed in this area to come to strong policy conclusions. Similar to what is needed for assessing degree of competition, better data on price and costs at the level of individual products may help.

A question associated with the harmonization across financial services providers is the balance between the costs and benefits of single versus multiple supervisory agencies. ${ }^{10}$ No simple answer here exists either, from the point of view of financial stability or from the perspective of efficiency of financial services provision. Although there is a move towards single supervisory authorities across the world, which presumably could help with reducing unnecessary differences arising from multiple regulatory regimes, this is not a general trend. Some countries, the Netherlands for example, have recently adopted the model of integrating systemic stability and all individual prudential oversight — banking, insurance and pension — in one agency, but separate from the agency for market conduct supervision. Others have left systemic stability with the central bank, but organized prudential and market conduct under two separate agencies. Yet others have not made any changes and have separate (and multiple) prudential banking, securities markets and insurance supervisors operating in one country, e.g., the U.S.

Whether any of these institutional arrangements are superior from the point of view of efficient financial services provision has not been researched and may remain unclear in any case given the difficulty of attribution. Differences in the degree of de-jure or de-

\footnotetext{
${ }^{10}$ The issue of consolidated supervision is less debated.
} 
facto harmonization (or lack thereof) among financial instruments are not obvious between these supervisory regimes. Even where there is a single supervisory authority, it has not done away with all (or even many) of the regulatory harmonization issues across sectors or products. Presumably, competitive pressures from the financial services industries and the lobbying strength relative to regulators will be the most important factors driving the (de-factor) reduction in barriers. In that respect, more fragmentation of regulation and supervision may well lead to more de-facto harmonization as financial services industries are stronger positioned to argue for regulatory changes and agencies "compete" with each other for influence." And the organization of a supervisory authority in a single country will be of little relevance for the degree of harmonization on a global basis.

Regionally and globally, harmonization issues are further compounded. Harmonization across markets or countries is a very complex undertaking. The EU, which has been engaged for quite some time now in financial integration and harmonization, shows the tenacity needed to create a single market for financial services. It has shown that requiring uniformity in regulations - in the form of Directives - is not sufficient since inconsistencies with national rules and laws still arise, also as other policy areas need to be adjusted, which takes much time and effort. The EU and other regionally experiences show not only how difficult harmonization is in practice, but also that conceptually difficult questions arise. For example, liquidity support and lender of last resort facilities in the EU are still national, but this can creates inconsistencies with policies for dealing with financial insolvency. Although liquidity management may be done centrally by the foreign bank in its home country, branches of foreign banks are typically eligible to receive liquidity support from the local host central bank. In case of insolvency of the head bank, however, the home country authorities are responsible, which can involve home government resources in case the whole bank fails. Furthermore, in the EMU, monetary policy is centralized, requiring coordination between member countries’

\footnotetext{
${ }^{11}$ Obviously, this is highly context and country dependent, and ignores many other dimensions. For example, with strong financial institutions and weak regulators, in some countries a greater influence of private interests could lead to lax and low-cost standards, with perhaps greater competitiveness, but with more risks of financial instability. In other environments, the capture of the regulator may lead to rentseeking, but with limited risks.
} 
liquidity support and ECB's monetary policy. The obvious policy solution-a single supervisor in the EMU with access to its own fiscal resources in case of financial insolvencies requiring government support-is a long way off in most observers' assessment. Yet, these differences have in turn competitive implications as some banks have more generous access to the safety net.

Harmonization is not just regional these days, but depends to a great extent on international standards, of which the ones developed by the BCBS, IOSCO, IAIS and CPSS are the most visible. This has become a large body of "soft law". ${ }^{12}$ The ambition level of these standards varies, from a minimum common denominator of existing national requirements to going beyond existing national requirements, as in Basel II. Although the standards are voluntary in nature and implementation is left to the countries themselves, some of the standards are quite intrusive. Adapting the many broad-based, global principles to individual country circumstances, while maintaining a common framework, has proven difficult. Difficulties range from the very narrow to the broad. For example, some countries have corporations with two supervisory boards, some with one, making uniform standards for corporate governance somewhat more difficult. And the Basel II rules encourages international banks to use the same risk management approaches across national jurisdictions, but uniform application would have the consequence that credit risks may be priced too rich in some countries and too thin in other countries. Adapting the model to capture the risks in various markets appropriately would be necessary, but would negate some of the gains of uniformity.

\footnotetext{
${ }^{12}$ There are issues of the legitimacy and governance of the standards setting bodies.
} 


\section{Special challenges facing developing countries in financial regulation}

There are some special challenges facing financial sector regulators and policy makers in developing countries. On one hand, developing countries are very rapidly integrating with global financial markets. In the application of (international) regulations and best practice supervision, as also reflected in the IMF/World Bank FSAP program, it is clear, however, that for developing countries the globally common approaches can be difficult. Many of the difficulties have to do with capacity constraints, making approaches adopted elsewhere not easily implemented in these countries' weaker institutional environments. But, also issues of overall approach and sequencing have come up. We organize these challenges as they relate to cross-border financial services activities and other international dimensions, volatility and access; sequencing and development strategies, and application and adaptation of standards to the local circumstances; and political economy. We first document though why developing countries perhaps more than other countries need to adapt quickly: most are financial integrating rapidly and many emerging markets are financially more integrated today than most developed countries are.

3.1 International financial integration. Gross capital flows—not necessarily net flows - and other forms of cross-border financial services provision-such as equity listing and trading on international stock markets - have increased sharply for many developing countries in recent decades, albeit for some countries from low bases. Much of this has been private to private flows, rather than the official or private to sovereigns flows in the 1970s. Entry in banking systems has been very large in some emerging markets in the last decade, with market shares of foreign banks in many emerging markets currently exceeding 50\%. These forms of financial integration have all been very rapid, at least compared to what happened in the past for the case of the now developed countries - many developed countries took more than 50 years after World War II to completely open up their financial sectors and capital account. Even then, many of them do not experience the same degree of international financial integration in terms of say foreign bank presence as some emerging markets do today. This rapid 
financial integration is thus forcing many adjustments in a short period of time in developing countries. At the same time, many developing countries face great difficulties: while they need rapid institutional capacity building, they lack financial and human resources. This means there are some issues facing developing countries in which they may need some special policy approaches.

3.2 Cross-border activities, volatility and access. There are many regulatory issues associated with cross-border financial services provision that are especially challenging for developing countries (see Caprio, Evanoff, and Kaufman, 2006). Some are technical, as regarding the regulation and supervision of foreign bank branches/subsidiaries that can be more important in emerging markets. On many of these issues there is not yet a clear consensus at to what is the best approach, and even when it exists, implementing it, including negotiating the (many bilateral) agreements, can be complex. For example, what is the best mode of information sharing, what is the liability —of the local deposit insurance agency or other entity - for deposits of foreign banks' subsidiaries and branches, etc. remains unclear. Similarly, the current framework for resolving weak foreign banks' branches or subsidiaries is not consistent across countries and surely complex, possibly leading to risks. In capital markets, large foreign ownership and the large trading and capital raising at stock exchanges off-shore in international financial centers, such as New York and London, can mean that responsibilities for oversight of capital markets' activities become unclear.

While most of these issues are germane to many countries, the large share of foreign presence in banking and the large foreign capital market participation—both foreigners operating in the local market and local institutions using off-shore markets-make these issues more important for developing countries. Developing countries are further burdened by weaker capacity. Clearly, with large internationalization, the costs of compliance with different regimes and multiple reporting for regulatory and other purposes increase, which is a greater burden for developing countries. Information sharing among supervisors and regulators of different countries is often based on longterm relationships and trust, putting developing countries that are recently integrating at a 
disadvantage. The risk of a single banking failure or a systemic banking crisis is typically larger in a developing than in a developed country, making the lack of clarity regarding cross-border arrangements for the resolution of failed banks potentially more unfavorable for developing countries.

The lack of a clear framework make countries respond in ways that can create costs and distortions. The common requirement, for example, to establish subsidiaries instead of branches reflects in part the lack of certainty among supervisors on how to deal with branches in the absence of a solid international framework. The desire for subsidiaries creates costs, however, for international banks in terms of tying up capital inefficiently, and can create new risks. Combined with limited capacity, this incomplete international framework can be of particular disadvantage for developing countries.

The large foreign bank presence in some emerging markets specifically has raised concerns of introducing volatility as well as having adverse impact on access to financial services by some classes of local borrowers and consumers. On both, however, the evidence is largely reassuring: cross-border financial services provision does not seem to lead to increased volatility or reduced access by SMEs or consumers in developing countries (Claessens 2006 reviews). Even when increased cross-border banking may have to less access for some classes of borrowers, this may be an acceptable tradeoff given other benefits. First, cross-border banking has been found to lead to more stability and more efficient financial systems Second, not all of the access prior to foreign entry was likely efficient; often - especially in closed financial systems-domestic banks extend financial services on a preferential basis to some groups.

Nevertheless, some genuine concerns on access can arise. A theoretical argument can be made that, given their skills and more formal based processes, foreign financial service providers focus too much on the high end of the corporate sector market and on consumer finance. As a consequence, access by medium-sized firms with more informationallyintensive needs to lending and other financial products may be relatively less with large 
foreign entry. The empirical importance of this possibility is not known, and if important enough, the proper policy responses to mitigate are as of yet unclear.

There can be other financial sector developmental aspects as well. The fact that a large share of the banking system is owned by foreign banks can hinder local information generation and information availability, which in turn can affect supervisory quality. Large foreign banks presence can, for example, mean that the local supervisors have less knowledge on the state of the local economy as they do not know the nature of local bank lending as well. Market discipline may work differently as well. When the local operation represents only a small part of the foreign financial institution's overall balance sheet and income, the effects of market discipline in the home market on the operations in the local market may be limited. There may also be negative effects on local capital markets development when foreign banks are no longer listed. This may reduce not only local capital markets liquidity directly, but can also mean a lack of market signals (e.g. financial performance, price and ratings) regarding the performance of local banks and related of the local economy more generally (see further Graf and O’Dogherty, 2006 for some of these effects and possible policy responses).

Similar effects can occur in capital markets. The rapid international financial integration of emerging markets has led to many gains, in the form of lower costs of capital, increased liquidity, better price discovery and improved diversification of risk. Yet, some, still nascent capital markets in emerging economies have suffered from internationalization through declines in local liquidity, in turn negatively affecting the prospects of local capital market development. This has happened in particularly in Latin America, where the pull from New York in terms of cross-listing and trading has been very strong. The internationalization of these markets has already negatively affected the remaining local firms in a narrow sense - as declines in local liquidity make it more difficult to trade and raise new capital for the remaining other, smaller firms - and in a broad sense - as business becomes too limited to support local investment banking activity, accounting services, trading systems and the like. Again, while not unique as 
there has been a consolidation of stock market activities globally, these effects are of particular importance for many emerging markets.

The best regulatory responses in either banking or capital markets are not clear. In banking, some have proposed and implemented specific corporate governance requirements for subsidiaries, to avoid the repercussion of problems in the home markets affecting the local markets and more generally to address possible conflict of interests between headquarter and local operations. The Basel Committee has also started to address the special issues of corporate governance of banks' subsidiaries (e.g., including a statement: "the corporate governance responsibilities of both the bank and its parent should be respected"). Some have suggested that subsidiaries of foreign banks should be listed in the local markets, even when fully or largely owned by one parent bank, to assure some price discovery in the local markets. This can have some benefits, but possibly at a cost that will be passed on to consumers (these costs can include the direct costs of regulatory compliance and indirect costs as when the cost of capital is higher in the host than the home market or when liquidity is the host market is more limited).

Issues in emerging capital markets can be complex as well. On one hand, harmonizing rules and regulations with those in international markets may reduce the incentives to divert trading and capital raising from emerging to international markets. Full harmonization—including enforcement—could, for example, preclude firms from listing in international financial centers to bind themselves to higher corporate governance or disclosure standards. On the other hand, as liquidity attracts liquidity, more common standards may just facilitate the agglomeration of trading in one place, as has been found in say the derivatives markets where most trading in (near) identical contracts is typically concentrated in one place. Rather, the presence of some differentiation in say listing rules, and other "frictions", combined with home bias and the tendency for markets to be most active near the center of information production, may lead to more active local markets. This would suggest that local regulations in emerging markets ought to aim at (some) differentiation from international markets to maintain activity. Again, the best regulatory responses are not clear and may differ by the size, location and other aspects 
of the local emerging markets. It may be, for example, that smaller markets with close geographic or time-zone proximity to large markets may be best off fully integrating, whereas larger markets further removed from financial centers may be able to pursue a more differentiated strategy.

3.3 Development strategies and international standards. The large foreign entry and offshore activities, the increased general financial integration and the greater importance of global standards are raising some fundamental issues of sovereignty and compatibility of foreign financial institutions - with for profit motives - with local financial sector development objectives. While financial integration and foreign financial institutions bring much value added, it does restrict the degrees of freedom of local policy makers. To a large extent, the reduced degree of sovereign freedom is part of globalization and has had many benefits, not least as a disciplining factor, since the role of the state in the financial sector has not always been beneficial in most developing countries. At the same time, many now developed economies have had a large role of the state in the past in financial intermediation.

Whether there is (still) scope for differentiated national development strategies, given the current degree of financial integration and the global financial, economic and political pressures is unclear. As such, it raises the question whether the best approach is one of a fully liberalized system. If one nevertheless thinks that financial sector development in developing countries today can be pursued on a country-specific approach, one has to consider the modalities. Technically, local financial sector development can still be pursued in ways different from those prevailing in global financial markets. Governments can still pursue specific objectives through the financial system, including some larger (direct or indirect) role of the state in financial intermediation. National treatment under the GATS and WTO, for example, does not prevent the application of limits of allowable forms of financial services provision or specific measures aimed at local development, e.g., lending requirements for small and medium enterprises (SMEs), agricultural finance or housing finance, as long as they are applied in a nondiscriminatory manner. The measures and modalities will of course have to consider the 
effects they have on attracting (or losing) foreign financial institutions and other distortive effects.

Regardless, there may be elements in which national development strategies need to be adjusted to account for the large foreign participation. With a large foreign presence, for example, there maybe a larger role for the state in alleviating coordination issues as foreign financial institutions will not internalize as much the effects they have on local financial markets. A small emerging market with largely foreign banks, for example, may be subject to large spillovers arising from foreign financial markets. The limited ability to coordinate among foreign players using moral suasion and other tools, may call for greater government intervention (in a transparent manner). It may well be that an intermediate stage of financial integration, in which there is a large foreign presence or large internationalization, but not yet a fully integrated institutional environment, represents the most risky state.

Application and adaptation of international standards. As has become clear, adopting international financial sector standards can be challenging for developing countries. While standards needs adaptation —as there is not a one size that fits all countries, in their design, by default, standards have a bias towards the circumstances of (current) developed countries, including a more liberal institutional environment, and these countries' regulation and supervision structures. Developing countries are further from the paradigm reflected in the standards and have greater implementation challenges. Standards are often too sophisticated for many developing countries and assume too much in terms of the supporting institutional infrastructure. To a large extent, overcoming or alleviating these problems requires actions in developing countries: better laws and regulations and institutional capacity building, supported by technical assistance, etc. This will take much time, however, and in the meantime inefficiencies from using the wrong "standards" may be considerable and (new) risks even may arise. What to do instead is unclear, however. 
Trying to adopt all standards in their entirety is surely inefficient for almost all (developing) countries. Some parts of the financial system may not yet be developed (e.g., stock markets) and as such some standards (e.g., IOSCO) may be meaningless. And, depending on the country, some elements of the standards will be more important than others. Better prioritization which (elements of the) standards are more relevant for the circumstances of (specific) developing countries - and which would need to be implemented first — would be useful. General guidance would probably mean that the elements common to many of the standards-regulatory governance, governance, transparency—would be key to adopt and implement first. Little formal analysis exists, however, on what is most important given country circumstances. Countries are generally left to take decisions using their own judgment or relying on what can at times be ad-hoc international advice.

A broader issue is how to adapt (some of) the standards over time and to countries' circumstances. Here the issue of representation in and legitimacy of the standard setting bodies becomes important. While it is recognized that adaptation of the (application of) standards and the reform model to the circumstances of developing countries can be necessary, to date developing countries have had a small stake in the global standard setting bodies and their debates. Emerging markets' participation in global forums like the Financial Stability Forum, Basel Committee and other such groups, is still small. The influence of developing countries in the formulation of standards is consequently still limited.

Similar issues arise in the context of financial services negotiations - as in GATS and regional Free Trade Agreements (FTAs). Limited means (technical, financial and people) can put developing countries at a disadvantage in North-South type of FTAs. Not being able to influence the terms forces developing countries in the position of essentially facing take-it-or-leave-it offers that are largely based on the rules in developed countries. Chile's FTA with the U.S., for example, shows the difficulty of including the type of capital account restrictions that can be part of successful development strategies. 
This has costs in terms of the relevance of the standards to the situation of developing countries - as noted above, but also may have weakened their legitimacy, making it more difficult for developing countries to adapt these standards in light of domestic opposition. Governments and politicians in all countries have difficulty to make the case domestically for adopting these standards and joining FTAs. In case of developing countries, the large gap between local and international rules can make it more even difficult for policy makers to convince the general public and special interests of the need to adopt these new rules. In this sense, some overrepresentation in standard setting bodies and tilting the bargaining positions towards developing countries in trade negotiations rather than the opposite can help overcome these barriers.

Of course, legitimacy is as often used appropriately as it is misused and many countries hide behind "lack of legitimacy" when they do not implement reforms that are in their general interest, but not favored by special interests. In general, the process of standards setting, the adaptation of standards to different and changing circumstances, the manner in which compliance with standards is being verified, the growing importance of regional and global trade agreements, and the legitimacy of the global financial system are deep and complex issues on which further analysis is necessary to assure that the needs of developing countries are appropriately met (see further Claessens and Underhill, 2005).

3.4 Political economy. Financial reform, maybe more so than other forms of reform, needs to consider the political economy of the country in questions. One clear aspect involving political economy factors is enforcement, which, is an issue in many developing countries. Overarching concern for developing countries with respect to the standards will be their enforcement. Institutional constraints and limited scope for enhancing capacity, are not just a matter of laws and technical implementation, but also of enforcement. Weak enforcement has been a symptom of development, some say development is all about enforcement (Nobel Laureate Douglass North argued that "how effectively agreements are enforced is the single most important determinant of economic performance;” North 1991). As such, enforcement will take some time to achieve and 
balancing public enforcement with other means — such as relying on private enforcement mechanisms — will be efficient.

Often some of the constraints regarding enforcement run much deeper than just lack of capacity and low pay of supervisors, but refer to the lack of political will, lack of accountability, and plain corruption. Without considering the political economy, reforms may not only be missing the real constraints, they may even aggravate the problems. For example, granting too much power to banking supervisors in an environment with limited accountability risks only misuse. The answer in less developed environments may be two-fold: first, in such countries more reliance needs to be given to market-based approaches in regulation and supervision; and second, some constraints and a less than fully liberalized environment may be attractive.

For the first, there is a long tradition of legal thinking and some specific recent empirical evidence in case of finance on the importance of private approaches. The general legal literature stresses that private enforcement mechanisms are likely to be the main mechanisms in most markets, particularly in countries with severe weaknesses in public law and public enforcement. Furthermore, in one view, public law emerges out of private ordering, at least it has so in common law systems; courts "find" well-functioning contractual arrangements among parties and elevate them to law. Furthermore, in most markets, private "enforcement" mechanisms have always been at work. Industrial standards, for example, are very commonly "enforced" in industries through a mixture of reputation and private sector organizations, witness the ISO-standards and the private enforcement thereof (see further Berglof and Claessens, 2006 for a review).

In terms of empirical evidence on enforcement issues in banking regulation and supervision specifically, Barth, Caprio and Levine (2006) show that giving more powers to bank supervisors does not work well, especially not in less developed countries, while private mechanisms work better. In the area of securities regulation (La Porta et al., 2006) show that mechanisms relying on private law enforcement are more effective for capital market development, while public enforcement mechanisms are less effective. 
This evidence suggests that the role of standards relying much on government enforcement is at best limited in developing countries and potentially perverse.

While standards relying on public enforcement and government actions may not be the solution, a fully liberalized private sector approach may neither be the best. Rather, there may be an argument to introduce some restraints on private sector actions. Claessens and Perotti (2005), argue that in some cases the best path of financial sector development may require quantity constraints. This may mean limiting initially the type of activities financial institutions can engage in to restrain risk (e.g., banks are not allowed to invest in real estate or undertake sophisticated financial transactions). It can mean limiting the degree of competition in some segments, both across institutions and geographically, while committing to relaxing it over time to prevent rent-seeking behavior. Such an approach can insulate at early stages financial markets from the potential for opportunistic abuse by insiders. This form of "quantity regulation”, as Glaeser and Shleifer (2000) argue, offers greater resistance to manipulation than more sophisticated regulatory approaches (based on prices, financial reporting, etc.), particularly in institutional environments where information is weak and political economy factors are strong.

Yet, neither private sector monitoring nor quantity restraint approaches are fully compatible with the international standards and their implied financial sector development approach. Relying more on the private sector monitoring approach could, for example, imply that countries do not comply fully with (all) the 25 Basel Core Principles for Effective Banking Supervision (BCP) or some other international standards. While, as long as they put more emphasis on market forces, this may be the best approach, the signal from an evaluation under the BCP (as conducted as part of the Reports on the Observance of Standards and Codes) nevertheless would be negative as the country would show lack of compliance. Similarly, a greater reliance on private enforcement in securities markets may come at a "cost” of less compliance with IOSCO principles. 
Somewhat similarly, the quantity restraint approach could imply that the country maintains some barriers on capital account movements or between financial services providers, restricts competition geographically or across products, regulates banks' portfolio allocations, or controls the type of products financial institutions can offer. While these actions do not necessarily violate standards in a narrow sense, a deviation from the general reform model is nevertheless implied. As such, it can be a negative signal to the international financial markets. Without an adaptation of the standards, developing countries could risk a negative rating, which may hurt their development prospects.

\section{Conclusions}

There have been many changes in financial systems around the world over the past two decades. Regulators and policy makers have both led and reacted to these changes. Many lessons, sometimes costly, have been learned as to what regulatory approaches work in terms of promoting sound and efficient financial intermediation. There are also many areas on which there is still much debate and lessons still need to be drawn. And, as the financial services industries are undergoing continuous changes, new issues keep coming up. Some of the areas on which there still is much debate needed include the following:

The level playing field. How to assure that financial services are being provided most efficiently, regardless of the specific form chosen or of the characteristics of the specific financial services provider-location, institutional form or charter chosen, etc. This has proven to be difficult as financial services industries are undergoing so many changes, including leading to a different role for commercial banks, in the process altering their special nature. Further harmonization in some key regulatory dimensions will help to assure a level playing field, but it will have to be combined with enhanced competition to be most efficient going forward. In addition, policy will be have to be more focused on how any new risks will be managed and whether there can be adverse systemic impact. 
Competition policy. This is still a missing part of the financial sector development agenda in many countries. Too often, competition is left as an afterthought, rather than being considered an essential ingredient of a financial sector development strategy. This is especially so for developing countries that often have more entrenched systems, including through links between the financial and real sectors, and often relationships with the political sector as well. Competition can be a force for change, but to assure competitive markets will require taking into account the special properties of financial markets, including the existence of many networks in finance.

Consumer protection. With the increased diversity of financial services and providers, there is a need to shift more of the responsibility for choices to consumers. Yet, policy makers can not abrogate their responsibilities as easily —as consumers are still learning the new world and still living under the old paradigm. The shift also requires equipping the consumer with the proper information to make informed choices and with the proper regulatory and legal tools to seek redress in case of disputes. And it requires the consumers to be educated enough to make the "right" choices. All three are challenges facing regulators and policy makers around the world, not just in developing countries.

The role of standards. The adaptation in practice of global regulations to country circumstances, and the associated adjustment of the FSAP and ROSCs processes, will remain a continuous learning process. More attention will need to be given to how the standards are being designed and assessed, and how compliance is being communicated within the country and internationally. This is especially so for developing countries that can have very different systems and challenges, but that to date have had little participation in the formulation of the standards, their evolution, and how they are being assessed.

Developing countries' challenges. Developing countries faces some specific challenges in adapting to the rapid financial integration they experience. Cross-border banking and internationalization of financial services has been extensive in developing countries. In banking, this is leading to particular policy issues, such as the role of home and host 
supervisors, the exchange of information, and the potential volatility introduced by foreign banks. The rapid internationalization of stock markets' services, including through cross-listings, has made capital markets development strategies more difficult for many emerging markets. Answers to these issues will also require some adaptation to current financial sector development approaches. 


\section{References}

Barros, Pedro Pita, Erik Berglof, Paolo Fulghieri, Jordi Gual, Colin Mayer, Xavier Vives. 2005. “Integration of European Banking: The Way Forward”. Monitoring European Deregulation 3. Centre for Economic Policy Research (CEPR) and Fundacion BBVA. London, Spain. March.

Barth, James, Gerard Caprio and Ross Levine, 2006, Rethinking Bank Supervision and Regulation: Until Angels Govern. Cambridge, UK: Cambridge University Press.

Beck, Thorsten, 2006, Creating and Efficient Financial System: Challenges in a Global Economy, World Bank Working Research Paper 3856, February, Washington, D.C.

Berglöf, Erik and Stijn Claessens, 2006, Enforcement and Corporate Governance, World Bank Research Observer, 21:1, 123-150.

Boot, Arnoud W.A., and Anjolein Schmeits. 2005. The Competitive Challenge in Banking. Amsterdam Center for Law \& Economics (ACLE), Working Paper No. 200508.

Caprio, Gerard, Jr., Douglas Darrell Evanoff, George G. Kaufman (eds.), Cross-Border Banking: Regulatory Challenges, The Federal Reserve Bank of Chicago and the World Bank, World Scientific Studies in International Economics.

Calomiris, Charles, and Charles M. Kahn. 1991. The Role of Demandable Debt in Structuring Optimal Banking Arrangements. American Economic Review, June, 497513.

Claessens, Stijn, 2006, Competitive Implications of Cross-Border Banking, in Gerard Caprio, Douglas Darrell Evanoff, George G. Kaufman (eds.), Cross-Border Banking: Regulatory Challenges, The Federal Reserve Bank of Chicago and the World Bank, World Scientific Studies in International Economics.

Claessens, Stijn, Gergely Dobos, Daniela Klingebiel, and Luc Laeven, 2003. The Growing Importance of Networks in Finance and Its Effects on Competition, in Anna Nagurney (Ed.), Innovations in Financial and Economic Networks, Edward Elgar Publishers, Northampton, MA, USA, 110-135.

Claessens, Stijn, and Enrico Perotti, 2005, Finance and inequality: channels and evidence. Background paper for the World Development Report, 2006, mimeo World Bank and University of Amsterdam.

Claessens, Stijn and Geoffrey Underhill, 2005. The Need for Institutional Changes in the Global Financial System: An Analytical Framework, in Joost Teunissen and Age Akkerman (eds), Protecting the Poor: Global Financial Institutions and the Vulnerability 
of Low-Income Countries, J, Fondad Conference Series, The Hague, the Netherlands, 79114.

Claessens, Stijn, Geoffrey R. D. Underhill and Xiaoke Zhang, 2003, Basle II Capital Requirements and Developing Countries: A Political Economy Perspective, mimeo October, University of Amsterdam.

Cruickshank, Don, 2000, Review of Banking Services in the UK, Competition in UK Banking: A Report to the Chancellor of the Exchequer, at http://www.hmtreasury.gov.uk/documents/financial_services/banking/bankreview/fin_bank_reviewfinal. $\mathrm{cfm}$

Diamond, Douglas W., and Raghuram Rajan, 2001a, Liquidity Risk, Liquidity Creation and Financial Fragility: A Theory of Banking, Journal of Political Economy, vol. 109, No.2: 287-327.

European Commission, White Paper on Financial Services Policy 2005-2010, Brussels, December.

G-10, 2001, Report of the Group of Ten on Consolidation in the Financial Sector (so called Roger Ferguson Report), http://www.oecd.org/dataoecd/46/52/1896113.pdf

Gkoutzinis, Apostolos. Undated "How far is Basel from Geneva? International Regulatory Convergence and the Elimination of Barriers to International Financial Integration.” Mimeo. Harvard University

Glaeser, Edward and Andrei Shleifer. 2000. A Reason for Quantity Regulation, American Economic Review Papers and Proceedings 91 (2) (2001): 431-435.

Graf, Juan Pablo and Pascual O’Dogherty. 2006. Cross-Border Banking, Market Discipline and the Ability to Stand Alone, forthcoming in Kaufmann (ed.) Federal Reserve Bank of Chicago.

IMF, 2004, Financial Sector Regulation: Issues and Gaps, Prepared by Staff of the Monetary and Financial Systems Department, August 4, Washington, D.C.

Jayaratne, Jith and Philip E. Strahan, 1998, Entry Restrictions, Industry Evolution and Dynamic Efficiency: Evidence from Commercial Banking, Journal of Law Economics, Vol. 41, No.1: 239-273.

La Porta, Rafael, Florencio Lopez-de-Silanes, and Andrei Shleifer. 2006. What Works in Securities Laws? Journal of Finance 61(1), 1-32.

Levine, Ross 2005, Finance and Growth: Theory, Evidence, and Mechanisms. In P. Aghion and S. Durlauf, eds. Handbook of Economic Growth. Amsterdam: North-Holland Elsevier Publisher 
Morgan, Donald P., 2002, Rating Banks: Risk and Uncertainty in an Opaque Industry, American Economic Review, Vol. 92. No.4: 874-888.

North, Douglass C. 1991. Institutions, Institutional Change, and Economic Performance. Cambridge: Cambridge University Press.

OECD, 2005. Improving Financial Literacy: Analysis of Issues and Policies, December, Paris.

Padoa-Schioppoa, Tommaso, 2004, Regulating Finance: Balancing Freedom and Risk, Oxford University Press, Oxford, New York.

Rajan, Raghuram, 2005, Has Financial Development Made the World Riskier? IMF Working Paper, Washington, D.C. (also NBER Working Paper No. 11728)

Tirole, Jean. 2002. Financial Crises, Liquidity, and the International. Princeton University Press. Princeton and Oxford. New Jersey, Princeton. 


\section{Annex 1: 12 Key Standards for Sound Financial Systems}

The 12 standard areas highlighted here have been designated by the FSF as key for sound financial systems and deserving of priority implementation depending on country circumstances. While the key standards vary in terms of their degree of international endorsement, they are broadly accepted as representing minimum requirements for good practice. Some of the key standards are relevant for more than one policy area, e.g. sections of the Code of Good Practices on Transparency in Monetary and Financial Policies have relevance for aspects of payment and settlement as well as financial regulation and supervision.

\section{Area}

Macroeconomic Policy and Data Transparency

Monetary and financial policy transparency

Fiscal policy transparency

Data dissemination

Institutional and Market

Infrastructure

Insolvency

Corporate governance

Accounting

Auditing

Payment and settlement

Market integrity

Financial Regulation and Supervision

Banking supervision

Securities regulation

Insurance supervision
Standard

Code of Good Practices on Transparency in Monetary and Financial Policies

Special Data Dissemination Standard/

General Data Dissemination System $^{1}$

Principles of Corporate Governance

International Accounting Standards (IAS) ${ }^{3}$

International Standards on Auditing (ISA)

Core Principles for Systemically Important Payment

Systems

Recommendations for Securities Settlement Systems

The Forty Recommendations of the Financial Action Task

Force/

9 Special Recommendations Against Terrorist Financing

\section{Issuing Body}

IMF

IMF

IMF

World Bank

OECD

IASB $^{4}$

IFAC $^{4}$

CPSS

CPSS/IOSCO

FATF
Core Principles for Effective Banking Supervision

Objectives and Principles of Securities Regulation

Insurance Core Principles
BCBS

IOSCO

IAIS

1. Economies with access to international capital markets are encouraged to subscribe to the more stringent SDDS and all other economies are encouraged to adopt the GDDS.

2. The World Bank is coordinating a broad-based effort to develop a set of principles and guidelines on insolvency regimes. The United Nations Commission on International Trade Law (UNCITRAL), which adopted the Model Law on Cross-Border Insolvency in 1997, will help facilitate implementation.

3. Relevant IAS are currently being reviewed by the IAIS and IOSCO.

4. The International Accounting Standards Board (IASB) and the International Federation of Accountants (IFAC) are distinct from other standard-setting bodies in that they are private sector bodies.

Source: Financial Stability Forum 